\title{
Efektivitas Invigorasi Benih Cabai (Capsicum annuum L.) Kadaluarsa Menggunakan Rizobakteri Pemacu Pertumbuhan Tanaman
}

\author{
The Effectiveness of Invigorating Chili Seeds (Capsicum annuum L.) Expired Using \\ Rhizobacteria Booster Plant Growth \\ Hafiz Juanda $^{1}$, Syamsuddin ${ }^{1 *}$, Hasanuddin ${ }^{1}$ \\ ${ }^{1}$ Program Studi Agroteknologi, Fakultas Pertanian, Universitas Syiah Kuala \\ *Corresponding author: syamsuddin@unsyiah.ac.id
}

\begin{abstract}
Abstrak. Penelitian ini bertujuan untuk mengetahui Efektivitas Invigorasi Benih Cabai (Capsicum апnиит L.) Kadaluarsa Menggunakan Rizobakteri Pemacu Pertumbuhan Tanaman. Penelitian ini dilaksanakan di Laboratorium Ilmu dan Teknologi Benih Program Studi Agroteknologi Fakultas Pertanian Universitas Syiah Kuala Darussalam Banda Aceh. Penelitian dilaksanakan mulai pada bulan Januari 2020. Pada penelitian ini menggunakan Rancangan Acak Lengkap (RAL) faktorial 2X9 dengan dua faktor yang diteliti. Faktor pertama varietas (V) yang terdiri dari 2 taraf yaitu: V1 (Lado F1) dan V2 (Krida F1). Faktor kedua jenis Rizobakteri (R) yang terdiri dari 9 taraf yaitu $\mathrm{R}_{0}$ : Kontrol, $\mathrm{R}_{1}$ : Bacillus larvae, $\mathrm{R}_{2}:$ Pseudomonas capasia, $\mathrm{R}_{3}$ : Azotobacter sp. $\mathrm{R}_{4}$ : Acitinobacillus suis, $\mathrm{R}_{5}$ : Bacillus polymixa, $\mathrm{R}_{6}$ : Bacillus megaterium, $\mathrm{R}_{7}$ : Bacillus stearothermophillus, $\mathrm{R}_{8}$ : Bacillus lichiniformis. Dengan demikian terdapat 18 kombinasi perlakuan. Masing - masing kombinasi perlakuan diulang sebanyak tiga kali, dengan demikian terdapat 54 satuan percobaan. Peubah yang diamati adalah potensi tumbuh (\%), daya berkecambah (\%), keserampakan tumbuh (\%), indeks vigor (\%), kecepatan tumbuh relatif $(\%)$ dan $\mathrm{T}_{50}(\%)$. Hasil penelitian yang dilakukan menunjukkan bahwa interaksi antara rizobakteri jenis Azotobacter dengan varietas Lado F1 efektif dalam meningkatkan potensi tumbuh maksimum dan daya berkecambah. Interaksi antara rizobakteri jenis Bacillus polymixa dengan varietas Krida F1 efektif dalam meningkatkan potensi tumbuh maksimum dan daya berkecamabah.

Kata kunci : Benih cabai, rizobakteri dan varietas.
\end{abstract}

\begin{abstract}
This study aims to determine the effectiveness of the Invigoration of Expired Chilli (Capsicum Annum L.) Seeds Using Plant Growth Booster Rizobacteria. This research was carried out in the Seed Science and Technology Laboratory of the Department of Agriculture, Faculty of Agriculture, Syiah Kuala University, Banda Aceh. The study was conducted starting in January 2020. In this study used a $2 \mathrm{X} 9$ factorial Complete Randomized Design (CRD) with two factors examined. The first factor is variety (V) which consists of 2 levels, namely: V1 (Lado F1) and V2 (Krida F1). The second factor is the type of Rizobacteria (R) which consists of 9 levels, namely $\mathrm{R}_{0}$ : Control, $\mathrm{R}_{1}$ : Bacillus larvae, $\mathrm{R}_{2}$ : Pseudomonas capasia, $\mathrm{R}_{3}$ : Azotobacter $s p, \mathrm{R}_{4}$ : Acitinobacillus suis, $\mathrm{R}_{5}$ : Bacillus polymixa, $\mathrm{R}_{6}$ : Bacillus megaterium, $\mathrm{R}_{7}$ : Bacillus stearotherinoph, $\mathrm{R}_{8}$ : Bacillus lichiniformis. Thus there are 18 treatment combinations. Each treatment combination was repeated three times, thus there were 54 experimental units. The observed variables were growth potential $(\%)$, germination (\%), growth uniformity $(\%)$, vigor index $(\%)$, relative growth speed $(\%)$, and $\mathrm{T}_{50}(\%)$. The results of the research showed that the interaction between Azotobacter rizobacteria and Lado F1 varieties was effective in increasing maximum growth potential and germination. The interaction between Bacillus polymixa rizobacteria and Krida $\mathrm{F} 1$ variety is effective in increasing the maximum growth potential and the ability to contaminate.
\end{abstract}

Keywords: Chili seed, rhizobacteria and varieties.

\section{PENDAHULUAN}

Salah satu komoditi hortikultura yang banyak dibudidayakan oleh petani di Indonesia adalah tanaman cabai (Capsicum annuum L.). Selain itu, cabai memiliki beberapa manfaat kesehatan serta harga jual yang tinggi. Kandungan lasparaginase dan capcaicin yang terdapat didalam cabai dapat mengendalikan kanker. Cabai juga memiliki kandungan vitamin $\mathrm{C}$ yang cukup tinggi sehingga dapat memenuhi kebutuhan harian setiap orang (Kilham, 2006). Cabai tergolong dalam beberapa jenis yaitu cabai besar (Capsicum annuum L), cabai kecil (Capsicum frutescens), yang paling banyak dibududayakan oleh petani. Jenis sayuran ini mempunyai ciri aroma yang khas dan rasa pedas, sehingga dapat menggugah selera makan (Setiawati, 2005). 
Benih kadaluarsa yaitu benih-benih yang telah mengalami penurunan kualitasnya atau mengalami kemunduran sehingga apabila digunakan dalam usaha budidaya tanaman akan tumbuh terbatas dan hasilnya juga sangat terbatas. Benih yang sudah kadaluarsa dapat menurunkan viabilitas benih (kemampuan berkecambah). Kemunduran viabilitas suatu benih selama penyimpanan dapat diperlambat dengan cara memperhatikan kadar air, suhu dan kelembaban ruang, ada tidaknya mikroorganisme pada ruang dan keadaan udara disekitar ruang penyimpanan. Viabilitas benih dipengaruhi oleh beberapa faktor yaitu lingkungan sebelum panen, tingkat kemasakan benih saat panen, viabilitas awal benih dan juga lingkungan selama penyimpanan benih. Upaya peningkatan produktivitas tanaman cabai memerlukan dukungan benih yang bermutu. Penurunan kualitas benih yang bermutu juga dapat diakibatkan oleh penyimpanan yang kurang tepat atau benih telah melampaui masa hidupnya (kadaluarsa). Benih yang mengalami kemunduran masih bisa digunakan untuk ditanam, dengan melakukan perlakuan invigorasi yang tepat dan sesuai. Perlakuan invigorasi digunakan untuk menyeragamkan dan meningkatkan laju pertumbuhan kecambah. Proses invigorasi dapat mengendalikan air masuk ke dalam benih, zat pengatur tumbuh juga bertamah. (Kartasapoetra, 2003).

Viabilitas dan vigor benih dipengaruhi oleh faktor eksternal dan internal. Faktor eksternal berupa kemasan benih, komposisi gas, suhu, dan kelembaban. Faktor internal meliputi, sifat genetik, kondisi kulit benih, dan kadar air benih awal (Copeland dan McDonanld 2001).

Dasar dilakukannya invigorasi yaitu menjaga benih dalam situasi hidrasi sebagian dalam periode tertentu agar perkecambahan seluruhnya tertunda. Selama proses invigorasi, yang mengatur proses imbibisi air yaitu potensial osmotik larutan, agar tidak muncul radikula. Dilakukan invigorasi supaya dapat memperbaiki perkecambahan dan daya tumbuh kecambah saat tanam (Moradi dan Younesi, 2009).

Invigorasi bisa mengembalikan keadaan benih yang sudah menurun viabilitasnya. Invigorasi yaitu perlakuan fisik, fisiologis, dan biokimia dalam mengoptimalkan viabilitas benih agar benih bisa tumbuh cepat dan serempak pada situasi yang seragam. Invigorasi merupakan suatu perlakuan awal pada benih melalui pengontrolan imbibisi air oleh potensial air yang rendah dari media imbibisi. Selama invigorasi, terjadi perbaikan fisiologi dan biokimia yang berhubungan dengan peningkatan kecepatan tumbuh, keserempakan perkecambahan dan potensi perkecambahan (Khan, 1992).

Pemberian rizobakteri sangat berguna bagi tanaman, karena memacu terbentuknya fitohormon dan berperan dalam menginduksi ketahanan tanaman terhadap penyakit. Pengaruh induksi ketahanan ditandai adanya jumlah asam silisilat dan pathogenesis relate protein (Ibrahim, 2014).

Menurut Herman et al. (2008) Bakteri akar pemacu pertumbuhan tanaman (plant growth promoting rhizobacteria) sangat banyak dikembangkan, dalam usaha meningkatkan produksi pangan dan memperbaiki kualitas hidup. Penggunaan PGPR untuk mengurangi bahan kimia dalam pertanian

\section{METODE PENELITIAN}

Penelitian telah dilaksanakan di Laboratorium Ilmu dan Teknologi Benih Jurusan Agroteknologi, Fakultas Pertanian Universitas Syiah Kuala, Banda Aceh. Penelitian dilaksanakan mulai tanggal 4 s/d 18 Januari 2020. 


\section{MATERI DAN METODE}

\section{Alat dan Bahan}

Alat yang digunakan dalam penelitian ini mencakup autoclave, laminar airflow cabinet, timbangan analitik, oven listrik. ruang inkubasi, jarum ose, lampu bunsen, petridish, erlemeyer, keranjang plastik, gelas ukur, pinset, handspray, cup plastik dan berbagai peralatan lainnya yang dibutuhkan dalam penelitian ini. Sedangkan bahan yang digunakan yaitu benih cabai varietas Krida F1, varietas Lado F1, masa kadaluarasa varietsa Krida F1 pada bulan Juli2019, dengan viabilitas awal 85\%, sedangkan masa kadaluarsa varietas Lado F1 yaitu pada bulan September 2018, dengan viabilitas awal $85 \%$, banyak benih yang digunakan dalam satu cup yaitu sebanyak 10 benih, isolat rizobakteri yang diperoleh dari koleksi Laboratorium Ilmu dan Teknologi Benih Fakultas Pertanian Universitas Syiah Kuala, media PDA (Potato Dextrose Agar), alkohol 70\%, kertas stensil (buram), aquades dan spirtus.

\section{Rancangan Penelitian}

Pada penelitian ini menggunakan Rancangan Acak Lengkap (RAL) faktorial 2X9 dengan dua faktor yang diteliti. Faktor pertama varietas (V) yang terdiri dari 2 taraf yaitu: V1 (Lado) dan V2 (Krida). Faktor kedua jenis Rizobakteri (R) yang terdiri dari 9 taraf perlakuan yaitu: $\mathrm{R}_{0}$ : Kontrol, $\mathrm{R}_{1}$ : Bacillus larvae, $\mathrm{R}_{2}$ : Pseudomonas capasia, $\mathrm{R}_{3}$ : Azotobacter $s p . \mathrm{R}_{4}$ : Acitinobacillus suis, $\mathrm{R}_{5}$ : Bacillus polymixa, $\mathrm{R}_{6}$ : Bacillus megaterium, $\mathrm{R}_{7} \quad$ : $\quad$ Bacillus stearothermophillus, $\mathrm{R}_{8}:$ Bacillus lichiniformis

Dengan demikian terdapat 18 kombinasi perlakuan. Masing-masing kombinasi perlakuan diulang sebanyak tiga kali, dengan demikian terdapat 54 satuan percobaan. Masingmasing kombinasi perlakuan varietas dan jenis rizobakteri yang dicobakan disajikan pada Tabel 1 .

\begin{tabular}{lccc}
\hline NO & $\begin{array}{c}\text { Kombinasi } \\
\text { Perlakuan }\end{array}$ & Varietas & Rizobakteri \\
\hline 1 & $\mathrm{~V}_{1} \mathrm{R}_{0}$ & Lado $\mathrm{F} 1$ & Kontrol \\
2 & $\mathrm{~V}_{1} \mathrm{R}_{1}$ & LadoF1 & Bacillus larvae \\
3 & $\mathrm{~V}_{1} \mathrm{R}_{2}$ & Lado $\mathrm{F} 1$ & Pseudomonas capasia \\
4 & $\mathrm{~V}_{1} \mathrm{R}_{3}$ & Lado $\mathrm{F} 1$ & Azotobacter sp. \\
5 & $\mathrm{~V}_{1} \mathrm{R}_{4}$ & Lado $\mathrm{F} 1$ & Acitinobacillus suis \\
6 & $\mathrm{~V}_{1} \mathrm{R}_{5}$ & Lado $\mathrm{F} 1$ & Bacillus polymixa \\
7 & $\mathrm{~V}_{1} \mathrm{R}_{6}$ & Lado $\mathrm{F} 1$ & Bacillus megaterium \\
8 & $\mathrm{~V}_{1} \mathrm{R}_{7}$ & Lado $\mathrm{F} 1$ & Bacillus Stearothermophillus \\
9 & $\mathrm{~V}_{1} \mathrm{R}_{8}$ & Lado $\mathrm{F} 1$ & Bacillus lichiniformis \\
10 & $\mathrm{~V}_{2} \mathrm{R}_{0}$ & Krida $\mathrm{F} 1$ & Kontrol \\
11 & $\mathrm{~V}_{2} \mathrm{R}_{1}$ & KridaF1 & Bacillus larvae \\
12 & $\mathrm{~V}_{2} \mathrm{R}_{2}$ & Krida $\mathrm{F} 1$ & Pseudomonas capasia \\
13 & $\mathrm{~V}_{2} \mathrm{R}_{3}$ & Krida $\mathrm{F} 1$ & Azotobacter sp. \\
14 & $\mathrm{~V}_{2} \mathrm{R}_{4}$ & Krida $\mathrm{F} 1$ & Acitinobacillus suis \\
15 & $\mathrm{~V}_{2} \mathrm{R}_{5}$ & Krida $\mathrm{F} 1$ & Bacillus polymixa \\
16 & $\mathrm{~V}_{2} \mathrm{R}_{6}$ & Krida $\mathrm{F} 1$ & Bacillus megaterium \\
17 & $\mathrm{~V}_{2} \mathrm{R}_{7}$ & Krida $\mathrm{F} 1$ & BacillusStearothermophillus \\
18 & $\mathrm{~V}_{2} \mathrm{R}_{8}$ & Krida F1 & Bacillus lichiniformis \\
\hline
\end{tabular}

Keterangan : V : Varietas Cabai kadaluarsa ; R: rizobakteri 


\section{Metode Penelitian}

Benih cabai kadaluarsa yang dalam kemasan di rendam dengan menggunakan aquades selama 24 jam. Kemudian benih cabai dikering anginkan pada suhu dan kelembaban yang optimum. Benih yang telah dikeringkan, dimasukkan kedalam botol kaca yang sudah diberi perlakuan rizobakteri ditutup dengan rapat dan disimpan dalam ruangan ber AC. Selain itu, penyimpanan yang tepat dimaksudkan agar benih memiliki viabilitas dan vigor benih yang tinggi. Benih yang telah diberi perlakuan menggunakan rizobakteri perlu dilakukan pengujian viabilitas dan vigor. Pengujian viabilitas dan vigor menggunakan metode Uji Di atas Kertas (UDK), benih tersebut ditanam diatas kertas merang yang telah disiapkan didalam cup plastik. Untuk menjaga agar kondisi perkecambahan tetap optimum, benih yang sudah ditanam ditempatkan dalam germinator.

Pengamatan dilakukan terhadap parameter viabilitas dan vigor kekuatan tumbuh benih serta pertumbuhan bibit umur 14 Hari Setelah Tanam (HST). Tolok ukur yang diamati meliputi potensi tumbuh maksimum, daya berkecambah, kecepatan tumbuh relatif, keserempakan tumbuh, indeks vigor, waktu yang dibutuhkan untuk mencapai 50 persen perkecambahan total relatif. Prosedur pengujian viabilitas dan vigor benih mengacu kepada ketentuan ISTA.

\section{Analisa Statistik}

Analis data menggunakan analisis ragam yang dilanjutkan dengan uji Beda Nyata Jujur (BNJ) apabila ada nilai signifikasi antarperlakuan pada taraf 5\%.

\section{HASIL DAN PEMBAHASAN}

\section{Pengaruh Varietas terhadap Kualitas Benih}

Berdasarkan hasil uji F maka didapatkan hasil rekapitulasi analisis ragam menunjukkan bahwa perlakuan varietas tidak berpengaruh nyata terhadap tolok ukur potensi tumbuh maksimum, daya berkecambah, dan indeks vigor, tetapi berpengaruh nyata terhadap tolok ukur keserempakan tumbuh. Sedangkan pada perlakuan RPPT berpengaruh sangat nyata pada tolok ukur potensi tumbuh maksimum, daya berkecambah dan keserempakan tumbuh, namun tidak berpengaruh nyata terhadap indeks vigor. Sedangkan perlakuan Interaksi antara varietas dan RPPT berpengaruh sangat nyata terhadap tolok potensi tumbuh maksimum. Sedangkan untuk tolok ukur daya berkecambah dan keserempakan tumbuh berpengaruh nyata, namun tidak berpengaruh nyata terhadap tolok ukur indeks vigor.

Tabel 2. Rekapitulasi Hasil Analisis Ragam (UJI F) Pengaruh Varietas dan Jenis Rizobakteri terhadap Beberapa Tolok Ukur Viabilitas dan Vigor Benih cabai Kadaluarsa

\begin{tabular}{lcccc}
\hline \multirow{2}{*}{ Tolok Ukur } & \multicolumn{3}{c}{ Perlakuan } & \multirow{2}{*}{ KK (\%) } \\
\cline { 2 - 4 } & $\mathrm{V}$ & $\mathrm{R}$ & $\mathrm{VxR}$ & \\
\hline Potensi Tumbuh Maksimum (\%) & $0,18 \mathrm{tn}$ & $4,36 * *$ & $2,80 * *$ & 15,17 \\
Daya Berkecambah (\%) & $0,86 \mathrm{tn}$ & $3,88 * *$ & $3,03 *$ & 13,32 \\
Keserempakan Tumbuh (\%) & $5,89 *$ & $3,01 *$ & $0,78 \mathrm{tn}$ & 16,78 \\
Indeks Vigor $(\%)$ & 0,06 tn & 2,13 tn & 0,09 tn & 12,68 \\
\hline
\end{tabular}

Keterangan: $^{* *}$ : Sangat nyata taraf 0,$01 ;{ }^{*}:$ Nyata taraf 0,05 ; tn: Tidak nyata taraf 0,$05 ; \mathrm{V}$ : Varietas; R: Rizobakteri; VxR: Interaksi antara varietas dan rizobakteri; KK: Koefisien Keragaman.

Tabel 2 menunjukkan bahwa keserampakan tumbuh tertinggi dijumpai pada perlakuan varietas Krida F1 yang berbeda nyata dengan varietas Lado F1. Selanjutnya pada 
potensi tumbuh maksimum, daya berkecambah dan indeks vigor secara statistik tidak ada perbedaana yang nyata, akan tetapi nilainya cenderung lebih tinggi dijumpai pada perlakuan varietas Kirida F1 dibandingkan dengan varietas Lado F1.

Tabel 3. Rata-rata potensi tumbuh maksimal (PTM), daya berkecambah (DB), kesempakan tumbuh (KsT) dan indeks vigor (\%) terhadap Varietas

\begin{tabular}{lcccc} 
Jenis Varietas & PTM (\%) & DB (\%) & KsT (\%) & IV (\%) \\
\hline Lado F1 & 62,22 & 54,07 & $46,07 \mathrm{a}$ & 44,07 \\
Krida F1 & 63,33 & 55,83 & $51,25 \mathrm{~b}$ & 44,17 \\
\hline BNJ 0,05 \% & - & - & 3,61 & - \\
\hline
\end{tabular}

Keterangan: Angka yang diikuti oleh huruf yang sama berbeda tidak nyata berdasarkan uji Beda Nyata Jujur (BNJ) pada taraf 0,05 .

\section{Pengaruh Perlakuan RPPT Terhadap Kualitas Benih}

Tabel 4 menunjukkan bahwa potensi tumbuh maksimum, daya berkecambah akibat rizobakteri tertinggi dijumpai pada perlakuan Bacillus polymixa yang berbeda nyata dengan kontrol, namun tidak berbeda dengan perlakuan lainnya. Pada keserempakan tumbuh akibat rizobakteri tertinggi dijumpai pada perlakuan Bacillus polymixa yang berbeda nyata dengan perlakuan Azotobacter sp, namun tidak berbeda nyata dengan perlakuan lainnya. Selanjutnya pada parameter indeks vigor secara statistik tidak ada perbedaan yang nyata, akan tetapi nilainnya cenderung lebih tinggi pada perlakuan jenis rizobakteri Bacillus polymixa, Bacillus megaterium dan Bacillus stearothermophillus.

Tabel 4. Rata-rata potensi tumbuh maksimal (PTM), daya berkecambah (DB), kesempakan tumbuh (KsT) dan indeks vigor (IV) terhadap jenis rizobakteri

\begin{tabular}{lcccc} 
Jenis Varietas & PTM (\%) & DB (\%) & KsT (\%) & IV (\%) \\
\hline $\mathrm{R}_{0}$ Kontrol & $48,33 \mathrm{a}$ & $45,00 \mathrm{a}$ & $40,00 \mathrm{ab}$ & 36,67 \\
$\mathrm{R}_{1}$ Bacillus larvae & $68,33 \mathrm{~b}$ & $61,67 \mathrm{~b}$ & $53,33 \mathrm{ab}$ & 46,67 \\
$\mathrm{R}_{2}$ Pseudomonas capasia & $70,00 \mathrm{~b}$ & $60,00 \mathrm{~b}$ & $53,33 \mathrm{ab}$ & 45,00 \\
$\mathrm{R}_{3}$ Azotobacter sp. & $60,00 \mathrm{ab}$ & $53,33 \mathrm{ab}$ & $39,00 \mathrm{a}$ & 41,67 \\
$\mathrm{R}_{4}$ Acitinobacillus suis & $63,33 \mathrm{ab}$ & $53,33 \mathrm{ab}$ & $50,00 \mathrm{ab}$ & 43,33 \\
$\mathrm{R}_{5}$ Bacillus polymixa & $71,67 \mathrm{~b}$ & $61,67 \mathrm{~b}$ & $55,00 \mathrm{~b}$ & 46,67 \\
$\mathrm{R}_{6}$ Bacillus megaterium & $70,00 \mathrm{~b}$ & $58,33 \mathrm{ab}$ & $51,67 \mathrm{ab}$ & 46,67 \\
$\mathrm{R}_{7}$ Bacillus stearothermophillus & $53,33 \mathrm{ab}$ & $48,33 \mathrm{ab}$ & $46,67 \mathrm{ab}$ & 46,67 \\
$\mathrm{R}_{8}$ Bacillus lichiniformis & $60,00 \mathrm{ab}$ & $53,33 \mathrm{ab}$ & $50,00 \mathrm{ab}$ & 45,00 \\
\hline BNJ 0,05\% & 17,66 & 13,58 & 15,17 & - \\
\hline Ken
\end{tabular}

Keterangan: Angka yang diikuti oleh huruf yang sama berbeda tidak nyata berdasarkan uji Beda Nyata Jujur (BNJ) pada taraf 0,05.

\section{Pengaruh Interaksi antara Varietas dan RPPT terhadap Kualitas Benih}

Berdasarkan hasil penelitian ditunjukkan bahwa terdapat interaksi yang beragam pada perlakuan benih cabai kadaluarsa dengan menggunakan beberapa jenis rizobakteri pada masing-masing taraf varietas dengan perlakuan beberapa jenis rizobakteri. 
Tabel 4 Pada tolok ukur PTM memperlihatkan bahwa kedua varietas yang dicobakan dengan menggunakan perlakuan rizobakteri memiliki nilai potensi tumbuh yang beragam. Pada varietas Krida F1 yang diberi perlakuan rizobakteri jenis Bacillus polymixa dan Bacillus larvae efektif dalam meningkatkan nilai potensi tumbuh maksimum yaitu $76,67 \%$ yang berbeda nyata dengan perlakuan rizobakteri jenis Azotobacter sp. dan Pseudomonas capasia varietas Lado F1 yaitu 73,33\%.

Tabel 5. Rata-rata Potensi Tumbuh Maksimum (\%) untuk Tiap Taraf Varietas pada Beberapa Jenis RPPT

\begin{tabular}{lrrl}
\hline \multirow{2}{*}{ Jenis Rizobakteri } & \multicolumn{2}{c}{ PTM $(\%)$} & \multirow{2}{*}{ BNJ 0,05 \% } \\
\cline { 2 - 3 } & Lado $\mathrm{F} 1\left(\mathrm{~V}_{1}\right)$ & Krida F1 $\left(\mathrm{V}_{2}\right)$ & \\
\hline $\mathrm{R}_{0}$ Kontrol & $43,33 \mathrm{Aa}$ & $53.33 \mathrm{Aa}$ & \\
$\mathrm{R}_{1}$ Bacillus larvae & $60,00 \mathrm{Aa}$ & $76,67 \mathrm{Ab}$ & \\
$\mathrm{R}_{2}$ Pseudomonas capasia & $73,33 \mathrm{Ab}$ & $66,67 \mathrm{Aa}$ & \\
$\mathrm{R}_{3}$ Azotobacter sp. & $73,33 \mathrm{Ab}$ & $46,67 \mathrm{Aa}$ & \\
$\mathrm{R}_{4}$ Acitinobacillus suis & $60,00 \mathrm{Aa}$ & $66,67 \mathrm{Aa}$ & \multirow{2}{*}{24,47} \\
$\mathrm{R}_{5}$ Bacillus polymixa & $66,67 \mathrm{Aa}$ & $76,67 \mathrm{Ab}$ & \\
$\mathrm{R}_{6}$ Bacillus megaterium & $70,00 \mathrm{Ab}$ & $70,00 \mathrm{Aa}$ & \\
$\mathrm{R}_{7}$ Bacillus stearothermophillus & $56,67 \mathrm{Aa}$ & $50,00 \mathrm{Aa}$ & \\
$\mathrm{R}_{8}$ Bacillus lichiniformis & $56,67 \mathrm{Aa}$ & $63,33 \mathrm{Aa}$ & \\
\hline
\end{tabular}

Keterangan: Angka yang diikuti oleh huruf yang sama berbeda tidak nyata berdasarkan uji Beda Nyata Jujur (BNJ) pada taraf 0,05 .

Potensi tumbuh maksimum menggambarkan viabilitas total benih (Sadjad et al., 1994). Nilai potensi tumbuh diperoleh dengan menghitung jumlah benih yang menunjukkan gejala tumbuh pada pengamatan sampai hari terakhir dan dinyatakan dalam persen. Gejala tumbuh ditandai dengan munculnya akar (radicle) atau plumula yang menembus kulit benih (pericarp).

Tabel 6. Rata-rata Daya Berkecambah (\%) Untuk Tiap Taraf Varietas Pada Beberapa Jenis RPPT

\begin{tabular}{lrcr}
\hline \multirow{2}{*}{ Jenis Rizobakteri } & \multicolumn{2}{c}{$\mathrm{DB}(\%)$} & \multirow{2}{*}{ BNJ 0,05\% } \\
\cline { 2 - 3 } & Lado $\mathrm{F} 1\left(\mathrm{~V}_{1}\right)$ & Krida $\mathrm{F} 1\left(\mathrm{~V}_{2}\right)$ & \\
\hline $\mathrm{R}_{0}$ Kontrol & $43,33 \mathrm{Aa}$ & $46,00 \mathrm{Aa}$ \\
$\mathrm{R}_{1}$ Bacillus larvae & $53,33 \mathrm{Aa}$ & $70,00 \mathrm{Ab}$ & \\
$\mathrm{R}_{2}$ Pseudomonas capasia & $60,00 \mathrm{Aa}$ & $60,00 \mathrm{Aa}$ & \\
$\mathrm{R}_{3}$ Azotobacter sp. & $63,33 \mathrm{Bb}$ & $43,33 \mathrm{Aa}$ & \\
$\mathrm{R}_{4}$ Acitinobacillus suis & $50,00 \mathrm{Aa}$ & $56,67 \mathrm{Aa}$ & \multirow{2}{*}{18,82} \\
$\mathrm{R}_{5}$ Bacillus polymixa & $56,67 \mathrm{Aa}$ & $66,67 \mathrm{Ab}$ & \\
$\mathrm{R}_{6}$ Bacillus megaterium & $60,00 \mathrm{Aa}$ & $56,67 \mathrm{Aa}$ & \\
$\mathrm{R}_{7}$ Bacillus stearothermophillus & $50,00 \mathrm{Aa}$ & $46,67 \mathrm{Aa}$ & \\
$\mathrm{R}_{8}$ Bacillus lichiniformis & $50,00 \mathrm{Aa}$ & $56,67 \mathrm{Aa}$ & \\
\hline
\end{tabular}

Keterangan: Angka yang diikuti oleh huruf yang sama berbeda tidak nyata berdasarkan uji Beda Nyata Jujur (BNJ) pada taraf 0,05 . 
Tabel 6 Pada tolok ukur daya berkecambah (DB) menunjukkan bahwa penggunaan rizobakteri pada benih secara nyata mampu meningkatkan daya berkecambah. Diantara semua perlakuan yang dicobakan yang diuji pada kedua varietas, perlakuan rizobakteri jenis Azotobacter sp. efektif dalam meningkatkan daya kecambah yang lebih tinggi pada varietas lado F1 yaitu 63,33\% yang berbeda nyata dengan perlakuan rizobakteri jenis Acitinobacillus suis, Bacillus stearothermophillus, Bacillus lichiniformis dan kontrol Lado F1. Sedangkan pada perlakuan rizobakteri jenis Bacillus larvae 70,00\% berbeda sangat nyata dengan perlakuan rizobakteri jenis Azotobacter sp, Bacillus stearothermophillus dan kontrol varieta Kirda F1.

Nilai daya berkecambah diperoleh dengan menghitung jumlah benih yang berkecambah normal pada pengamatan sampai hari terakhir, dihitung berdasarkan persentase kecambah normal (KN) hitungan pertama yaitu 7 Hari Setelah Tanam (HST) dan kedua yaitu 14 hari Setelah Tanam (HST) dan dinyatakan dalam persen.benih dikatakan telah berkecambah normal apabila akar telah tumbuh normal terutama akar primer dan akar sekunder. Plumula berkembang dengan baik dan telah memiliki dua daun serta terlepas dari kulit benih, tidak mengalami kerusakan baik pada hipokotil maupun plumula.

Hasil penelitian yang telah dilakukan didapatkan hasil bahwa interaksi antara varietas dan jenis rizobakteri berpengaruh dalam meningkatkan viabilitas dan vigor yang berbeda pada masing - masing taraf perlakuan yang digunakan, yang dapat dilihat pada tabel (3 dan 4). Hasil penelitian menunjukkan diantara kedua varietas yang dicobakan, varietas Krida F1 secara signifikan lebih tinggi dibandingkan dengan varietas Lado F1. Menurut Sadjad (1994), mengemukakan bahwa perbedaan daya tumbuh benih antar varietas ditentukan oleh faktor genetik. Gen sangat menentukan kemampuan metabolisme sehingga sangat mempengaruhi pertumbuhan dan perkembangan tanaman. Faktor lingkungan juga ikut berpengaruh terhadap suatu varietas jika dapat menyesuaikan diri pada kondisi lingkungan tumbuhnya agar dapat menghasilkan tanggap yang baik pada pertumbuhannya (Simatupang, 1997).

Interaksi antara rizobakteri jenis Azotobacter dengan varietas Lado F1 efektif dalam meningkatkan potensi tumbuh maksimum dan daya berkecambah. Kelompok rizobakteri dari hasil penelitian yang cukup efektif terhadap invigorasi benih kadaluarsa yaitu dari spesies Azotobacter sp. Ada dua pengaruh positif Azotobacter terhadap pertumbuhan tanaman, yaitu mempengaruhi perkecambahan benih dan memperbaiki pertumbuhan tanaman. Peranan bakteri ini terhadap perkecambahan tidak banyak diminati, meskipun demikian banyak penelitian yang mengarah pada peranan Azotobacter dalam meningkatkan daya kecambah benih tanamana tertentu (Sutanto, 2002).

Interaksi antara rizobakteri jenis Bacillus polymixa dengan varietas Krida F1 efektif dalam meningkatkan potensi tumbuh maksimum dan daya berkecamabah. Menurut (Sutariati et al 2006) menyatakan bahwa diantara berbagai isolat Bacillus sp. yang digunakan, isolat BG25 (Bacillus polymixa) memberikan dampak terbaik terhadap berbagai peubah perkecambahan benih cabai yang diamati. Rizobakteri dari kelompok Bacillus spp, mampu melarutkan fosfat serta juga mampu meningkatkan kesediaan $\mathrm{P}$ serta juga mampu mensintesis hormon IAA sehingga sangat menguntungkan bagi tanaman. 


\section{KESIMPULAN DAN SARAN}

Berdasarkan hasil penelitian dapat disimpulkan bahwa varietas berpengaruh nyata pada keserempakan tumbuh, namun berpengaruh tidak nyata pada potensi tumbuh maksimum, daya berkecambah, dan pada indeks vigor. Jenis varietas terbaik dijumpai pada Kirida F1. Rizobakteri berpengaruh sangat nyata terhadap potensi tumbuh maksimum dan daya berkecambah, serta berpengaruh nyata pada keserampakan tumbuh, namun berpengaruh tidak nyata pada indeks vigor. Perlakuan rizobakteri terbaik dijumpai pada rizobakteri jenis Bacillus polymixa.Terdapat interaksi yang berpengaruh sangat nyata antara pemberian rizobakteri dan varietas cabai terhadap potensi tumbuh maksimum, serta berpengaruh nyata pada daya berkecambah, namun berpengaruh tidak nyata pada keserempakan tumbuh dan indeks vigor. Kombinasi perlakuan terbaik dijumpai pada jenis rizobakteri Azotobacter dengan varietas Krida F1. Perlu dilakukan penelitian lebih lanjut menggunakan varietas yang berbeda untuk mengetahui efektivitas invigorasi benih cabai kadaluarsa dengan menggunakan rizobakteri pemacu pertumbuhan tanaman.

\section{DAFTAR PUSTAKA}

Copeland, L.O and M. B. McDonald. 2001. Principles of Seed Science and Technology. Kluwer Academic Publishers, London.

Herman MAB, Nault BA, \& Smart CD. 2008. Effect of plant growth-promoting rhizobacteria on bell pepper production and green peach a phid infestations in New York. Crop Protec. 27: 996 - 1002.

Ibrahim, N. 2014. Typical Teaching Methode Apllied in Chemistry experiment. Procedia. Social and Behavioral Science 116 (2014) 4946-4954. diakses 08 Januari 2020.

Kartasapoetra, A.G. 2003. Teknologi Penanganan Pascapanen. Bina Aksara, Jakarta.

Khan, A.A. 1992. Preplant physiological seed conditioning. In J. Janick (Ed.). Horticultural Review. Wiley and Sons Inc. New York. p.131 - 175.

Kilham, W. 2006. The First Of The Occurrence Of Anthracnose Disease Caused By Colletitrichum gloeosporoides (Penz) Penz. And Sacc. On Dragon Fruit (Hylocercus). America Journal Of Applied Science.6(5);902-912. Tersedia: http://www.scipub.org.

Moradi, A. and O. Younesi. 2009. Effects Of Osmo- And Hydro-Priming On Seed Parameters Of Grain Sorghum (Sorghum Bicolor L.). Australian Journal Of Basic And Applied Sciences, 3(3): 1696-1700.

Sadjad, S. 1994. Metode Uji Langsung Viabilitas Benih. Bogor : IPB.

Setiawati, Y. 2005. Analisis Varietas dan Polybag Terhadap Pertumbuhan Serta Hasil Cabai (Capsicum annuum L.) Sistem Hidroponik. Buletin Penelitian No. 8. Tersedia :http://research. Mercubuana.ac.id (Diakses 6 Januari 2020).

Simatupang, P. 1997. Akselerasi Pembangunan Pertanian dan Perdesaan Melalui Strategi Keterkaitan Berspektrum Luas. Pusat Penelitian dan Pengembangan Sosial Ekonomi Pertanian, Badan Penelitian dan Pengembangan Pertanian. Departemen Pertanian. Bogor

Sutanto, R. 2002. Pertanian Organik: Menuju Pertanian Alternatif dan Berkelanjutan. Kanisius, Yogyakarta. 
Sutariati, GAK, Widodo, Sudarsono, Ilyas S. 2006. Penagaruh Perlakuan Rizobakteri Pemacu Pertumbuhan Tanaman Terhadap Viabilitas Benih serta Pertumbuhan Bibit Tanaman Cabai. Bul. Agron. 34(1) : 46-54. 